\title{
GPS time series at Campi Flegrei caldera (2000-2013)
}

\author{
Prospero De Martino*, Umberto Tammaro, Francesco Obrizzo
}

Istituto Nazionale di Geofisica e Vulcanologia, Sezione di Napoli, Osservatorio Vesuviano, Naples, Italy

\author{
Article history \\ Received October 23, 2013; accepted February 12, 2014. \\ Subject classification: \\ Geodesy: measurements and monitoring, GPS, Time series, Campi Flegrei, Ground deformation.
}

\begin{abstract}
The Campi Flegrei caldera is an active volcanic system associated to a high volcanic risk, and represents a well known and peculiar example of ground deformations (bradyseism), characterized by intense uplift periods, followed by subsidence phases with some episodic superimposed mini-uplifts. Ground deformation is an important volcanic precursor, and, its continuous monitoring, is one of the main tool for short time forecast of eruptive activity. This paper provides an overview of the continuous GPS monitoring of the Campi Flegrei caldera from January 2000 to July 2013, including network operations, data recording and processing, and data products. In this period the GPS time series allowed continuous and accurate tracking of ground deformation of the area. Seven main uplift episodes were detected, and during each uplift period, the recurrent horizontal displacement pattern, radial from the "caldera center", suggests no significant change in deformation source geometry and location occurs. The complete archive of GPS time series at Campi Flegrei area is reported in the Supplementary materials. These data can be usefull for the scientific community in improving the research on Campi Flegrei caldera dynamic and hazard assessment.
\end{abstract}

\section{Introduction}

The Campi Flegrei (CF) caldera, which includes the western part of Naples, is an active volcano associated to a high volcanic risk [Ricci et al. 2013]. CF caldera is located in the southern part of the Plio-Quaternary Campanian Plain, where there are also others volcanic systems (Ischia, Procida and Somma-Vesuvius). Their volcanism is related to the spreading of the Tyrrhenian Basin, the collaps of the western margin of the Appennine chain and Campania Plain graben formation [Finetti and Del Ben 1986, Luongo et al. 1991a, Patacca and Scandone 2007, Vezzani et al. 2010]. The CF caldera last eruption, occurred in 1538, gave rise to Mt. Nuovo [Di Vito et al. 1987].

Many authors assign the most remarkable events in the CF volcanic history to the eruptions of the Campanian Ignimbrite and Neapolitan Yellow Tuffs (NYT) calderas occurred respectively at 40 and $15 \mathrm{ka}$. Since the
NYT eruption, the volcanic activity have been confined inside the caldera boundaries [Rosi and Sbrana 1987, Deino et al. 2004, Fedele et al. 2008, Isaia et al. 2009, Arienzo et al. 2011].

CF are known worldwide to be a site of notable slow vertical ground movements (bradyseism), testified by many submerged Roman ruins which are found along the coast of Pozzuoli Gulf, at nearly $14 \mathrm{~m}$ below sea level. These archeological ruins, as well as historical and recent observations, indicate that such phenomena have been active during the last 2000 years. Sinking has been then dominant process in historical times, but phases of uplift are also documented mainly from the well known evidence on the Serapeo columns (Roman market in Pozzuoli, the central part of the caldera) [Günther 1903, Parascandola 1947, Morhange at al. 1999, 2006].

The most recent uplift episodes occurred in 19701972 and 1982-1984 with a cumulative vertical displacement of about $3.5 \mathrm{~m}$ at the town of Pozzuoli, partially recovered successively. In addition to notable ground movements, the 1982-84 crisis was characterized by intense seismic activity with the occurrence of about 15,000 shallow earthquakes, with a maximum magnitude of 4.0. [Corrado et al. 1977, Barberi et al. 1984, Berrino et al. 1984, De Natale et al. 1991, Luongo et al. 1991b]. After 1984, small uplift episodes occurred in 1989, 1994, 2000 with maximum amplitude ranging between 1 and $7 \mathrm{~cm}$ [Del Gaudio et al. 2010]. From 2005, an inflation period has been detected [Troise et al. 2007] and, with increasing rates over time, is still ongoing. The overall uplift from 2005 to date is about $23 \mathrm{~cm}$.

The dense urbanization of the CF area, makes the monitoring of geophysical and geochemical parameters, linked to the eruption precursors, essential for an assessment of volcanic hazard and risk mitigation. Ground deformation is an important volcanic precursor, because it is linked to magma overpressure and migration. 
The Osservatorio Vesuviano (INGV-OV), department of the Istituto Nazionale di Geofisica e Vulcanologia, is in charge of monitoring the Neapolitan volcanic area. The monitoring system consists of several permanent networks, which provide seismological, geodetic and geochemical data. Continuous geodetic measurements are made using networks of tiltmeters, tide gauges and GPS stations. In particular, the permanent GPS network, called NeVoCGPS (Neapolitan Volcanoes Continuous GPS), provides stations 3D position over time [Bottiglieri et al. 2010, Vilardo et al. 2010, Tammaro et al. 2013].

With this paper we are providing GPS time series of the North, East and Vertical components of 14 stations of the NeVoCGPS network operating at CF area from 2000 to date.

The paper is organized as follows: in Section 2, we describe the data recording and data processing of $\mathrm{Ne}$ VoCGPS network; in Section 3, we present the time series of GPS stations in CF area, Section 4 is dedicated to the discussion, and finally Section 5 contains the conclusions.

\section{The NeVoCGPS network}

The NeVoCGPS network consists of 30 permanent stations located in the Neapolitan volcanic district and surrounding area (Figure 1).

All stations have been equipped with data transmission channels and with antennas to reduce multipath interference effect (choke-ring design).

Due to the high urbanization of the area and the considerable logistical constraints on siting (undisturbed view of the sky for clear signal reception, power connection, data transmission and instruments protection), most of the stations are monumented on the roof of stable buildings through three-dimensional forced centering devices for precise antenna set up. In some cases, concrete pillars anchored on bedrock are adopted.

At present, 14 stations of the NeVoCGPS network are operating at $\mathrm{CF}$ area (Figure 1). Some stations have been active since 2000 (Table 1).

\begin{tabular}{ccc}
\hline Station & $\begin{array}{c}\text { First observation } \\
(\text { decimal year })\end{array}$ & $\begin{array}{c}\text { Time span interval } \\
\text { (year) }\end{array}$ \\
\hline ACAE & 2000.1 & 13.5 \\
ARFE & 2000.7 & 12.9 \\
BAIA & 2000.1 & 13.5 \\
FRUL & 2008.1 & 5.5 \\
IPPO & 2000.0 & 13.6 \\
LICO & 2003.2 & 10.4 \\
MAFE & 2010.5 & 3.1 \\
MORU & 2007.8 & 5.8 \\
NISI & 2009.3 & 4.3 \\
QUAR & 2000.0 & 13.6 \\
RITE & 2000.4 & 13.2 \\
SOLO & 2009.1 & 4.5 \\
STRZ & 2008.0 & 5.6 \\
VICA & 2009.0 & 4.6 \\
\hline
\end{tabular}

Table 1. First observation and time span interval of the GPS stations used in this paper.
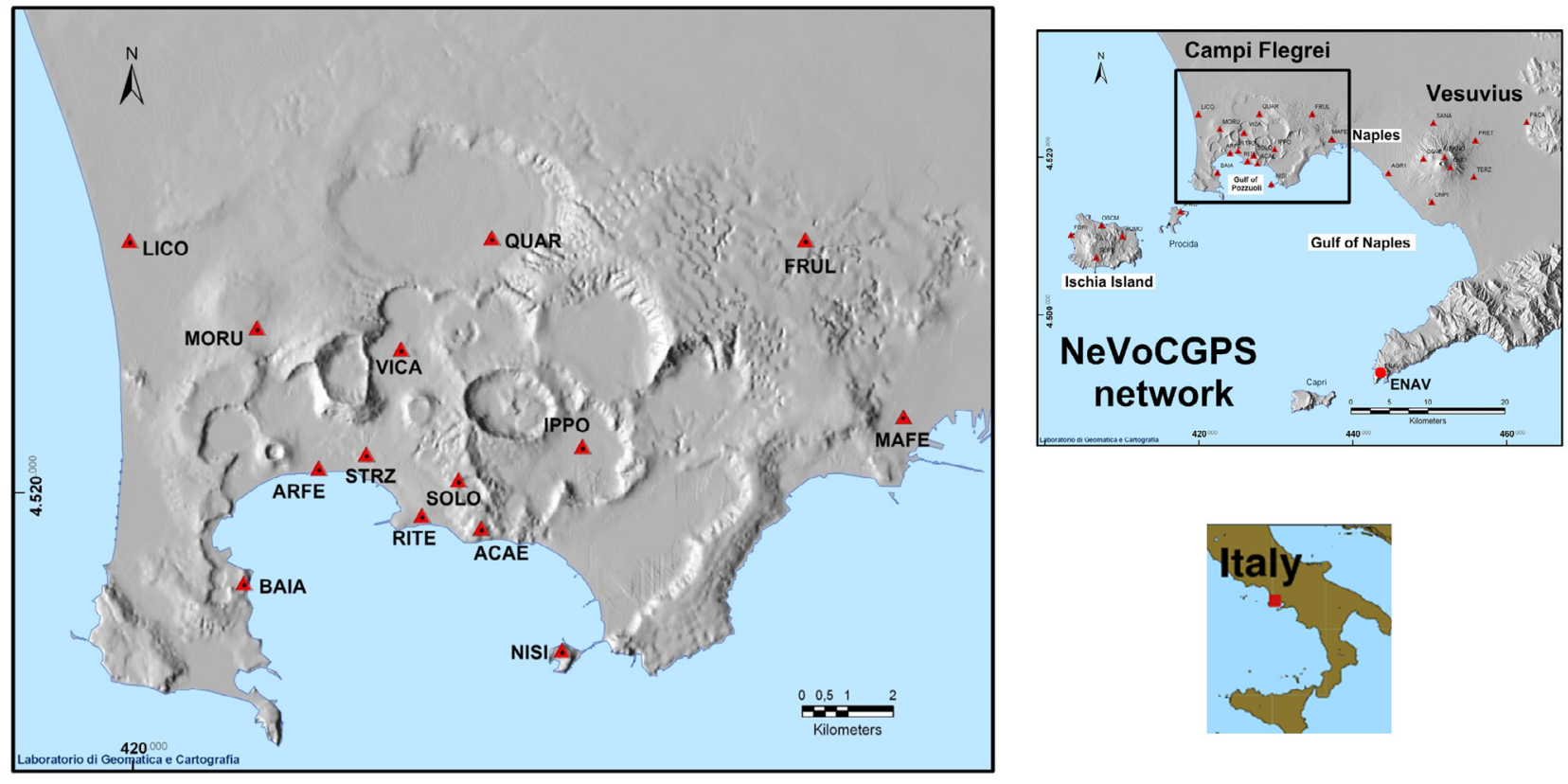

Figure 1. Map of NeVoCGPS network. Red triangles indicate GPS permanent stations. The box on the left shows CF area and the stations used in this paper. 


\subsection{Data recording}

Every day, 24 hours of observed dual-frequency GPS data, with 30 seconds sampling rate and 15 degrees cut-off angle, are downloaded from each site to the Osservatorio Vesuviano [Tammaro et al. 2013]. The data quality have to be quickly and accurately tested before their processing and storage in a database. The Osservatorio Vesuviano uses an in-house automatic application (SETA) for a quality check. It makes use of freeware programs, e.g. TEQC software, [Estey and Meertens 1999], to translate from the binary receiver format to the standard RINEX format, perform a quality check of the data and transfer the data files in an archive.

All the procedures for remote stations managing, raw data downloading, RINEX files generation and data quality control work automatically [Tammaro et al. 2013].

\subsection{Data processing}

Data processing is performed by the Bernese Processing Engine (BPE) of the Bernese GPS software v. 5.0 [Dach et al. 2007] in double difference mode. The data are processed on a daily basis using the Ultra-rapid International GNSS Service (IGS) products [Dow et al. 2009], in a fully automated processing chain. Once the IGS final orbits and Earth rotation parameters (ERPs) become available, the data are reprocessed on a weekly basis. The elevation cut-off is set at $15^{\circ}$ and the IGS absolute phase center variations for the satellite and receiver antennas are modeled.

Independent baselines are selected taking into account the criterion of maximum common observations. The ambiguity resolution is based on the Quasi Ionosphere Free analysis [Mervart et al. 1994]. Daily coordinates of the stations are estimated, together with the troposphere, in the final ionosphere free L3 solution. The dry part of the troposphere is modeled using the dry-Niell a-priori model and estimating the troposphere zenith delay parameters every hour at each site using the wet-Niell mapping function [Niell 1996].

The daily and weekly normal equations (NEQs) are saved for subsequent combination.

In order to get high-precision results, the utilization in the processing of homogeneous GPS products (orbits and ERPs), same correction models (e.g. antenna phase center variations) and precise and stable reference frame is essential.

During the time span (2000-2013) different improvements were introduced by the IGS into the processing strategies and modeling of global GPS solutions and different reference frames were adopted.

Since 2000, the IGS has used its own realizations of the successive ITRF releases as reference frames for its products. In November 2006, a reference frame based on ITRF2005 [Altamimi et al. 2007], called IGS05, was adopted by the IGS, simultaneously with the switch from relative (igs_01.pcv) to absolute antenna phase center calibrations (igs05.atx) [Schmid et al. 2007]. Because of growing velocity propagation errors and of jumps having affected the positions of many reference stations, IGS05 has become obsolete. So, a new reference frame based on ITRF2008, called IGS08, was designed and officially adopted by the IGS starting with GPS week 1632 (April 17, 2011). Furthermore, an updated set of absolute antenna calibrations (igs08.atx) was adopted [Rebischung et al. 2012].

These changes have made the previous IGS products inhomogeneous and inconsistent over time, introducing discontinuities into the time series of GPS station positions.

In order to get homogeneous results, all the GPS data of the NeVoCGPS network collected before November 2006, have been reprocessed using orbits and ERPs obtained by GPS-PDR reprocessing project of the global reference network based on absolute antenna phase center calibrations [Steigenberger et al. 2006].

Station specific discontinuities due to the antenna calibration updates from igs05.atx to igs08.atx are calculated with latitude-dependent correction models proposed by [Rebischung et al. 2012]. Also discontinuities associated with equipment changes (e.g., due to the replacement of antennas and/or tracking receivers, change of the radome on the antenna, firmware updates, etc.) are estimated. All discontinuities are introduced in the station information file as antenna eccentricities, and, after a final NEQs combination, we generate the updated time series of station coordinates.

The geodetic datum is realized by three No-Net Translation conditions imposed on a set of six IGS08

\begin{tabular}{cccc}
\hline Station & $\begin{array}{c}\text { North } \\
(\mathbf{m m})\end{array}$ & $\begin{array}{c}\text { East } \\
(\mathbf{m m})\end{array}$ & $\begin{array}{c}\text { Up } \\
(\mathbf{m m})\end{array}$ \\
\hline CAGL 12725M003 & -2.1 & 2.6 & -3.5 \\
GRAS 10002M006 & 2.5 & 3.3 & 0.9 \\
MATE 12734M008 & 2.5 & -3.4 & 2.2 \\
NOT1 12717M004 & -2.2 & -0.8 & 0.2 \\
WTZR 14201M010 & 0.9 & 2.3 & -3.5 \\
ZIMM 14001M004 & -1.4 & -4.0 & 3.7 \\
RMS / Component & 2.2 & 3.2 & 3.0 \\
RMS of Helmert & & $3.3 \mathrm{~mm}$ & \\
transformation & & & \\
\hline
\end{tabular}

Table 2. Residuals from Helmert transformation between IGS08 and our solution for the reference stations. 


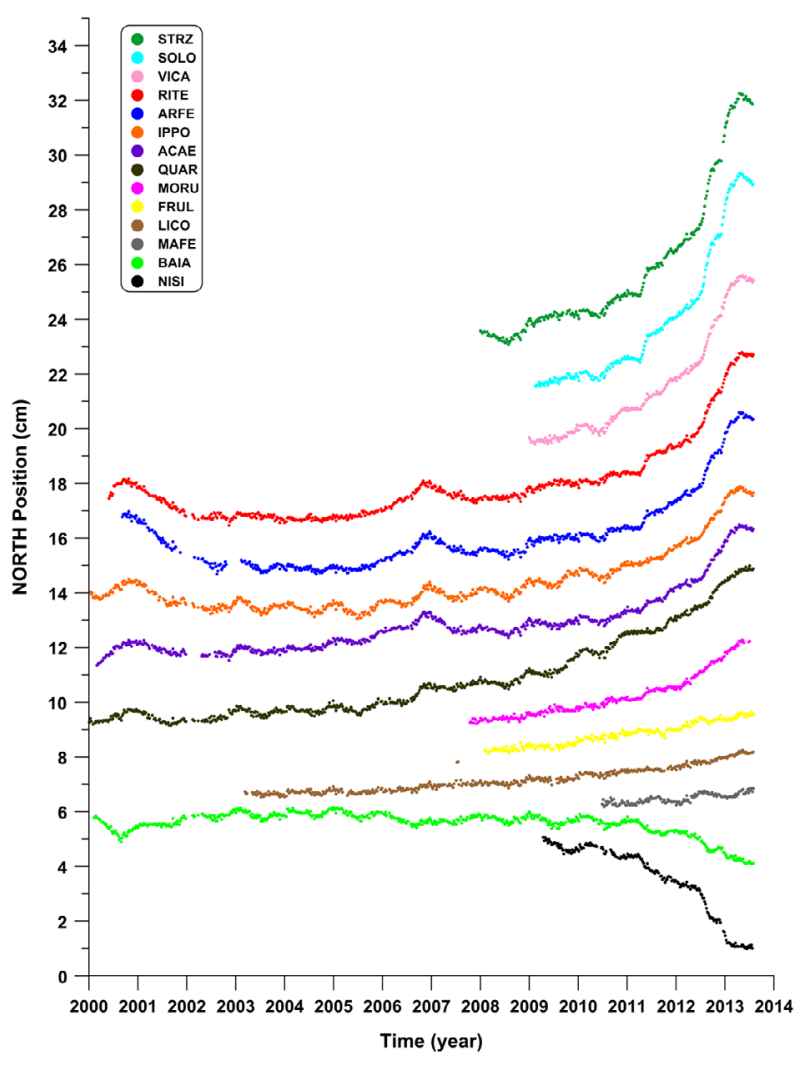

Clockwise from top left: Figure 2. GPS weekly time series of North component for CF stations relative to ENAV station. Uncertainties are not shown here, but are reported in data files (Supplementary material). Curves have been arbitrarily shifted for clarity. See Figure 1 for the location of the GPS stations. Figure 3. GPS weekly time series of East component for CF stations relative to ENAV station. Uncertainties are not shown here, but are reported in data files (Supplementary material). Curves have been arbitrarily shifted for clarity. See Figure 1 for the location of the GPS stations. Figure 4. GPS weekly time series of Vertical component for CF stations. Uncertainties are not shown here, but are reported in data files (Supplementary material). Curves have been arbitrarily shifted for clarity. See Figure 1 for the location of the GPS stations.

reference stations (Minimum Constraint Solution), which are included in the processing.

Table 2 shows the difference between the IGS08 coordinates and our estimated values for the reference stations. Residuals demonstrate the consistency of estimated coordinates with IGS08 at level of $3.3 \mathrm{~mm}$ in total RMS after the Helmert transformation.

\section{GPS time series}

The estimated IGS08 horizontal components (North and East) of the time series primarily reflect a rigid motion of the Eurasian plate with an average rate of about $2.5 \mathrm{~cm} / \mathrm{yr}$ in the NE direction. Therefore, to eliminate the global tectonic motion and highlight the volcanic deformation, we define a local reference frame based on the NeVoCGPS reference station ENAV, located on the limestones of Sorrento Peninsula, outside the volcanic area, and with long time span of measurements and constant horizontal velocities [De Martino
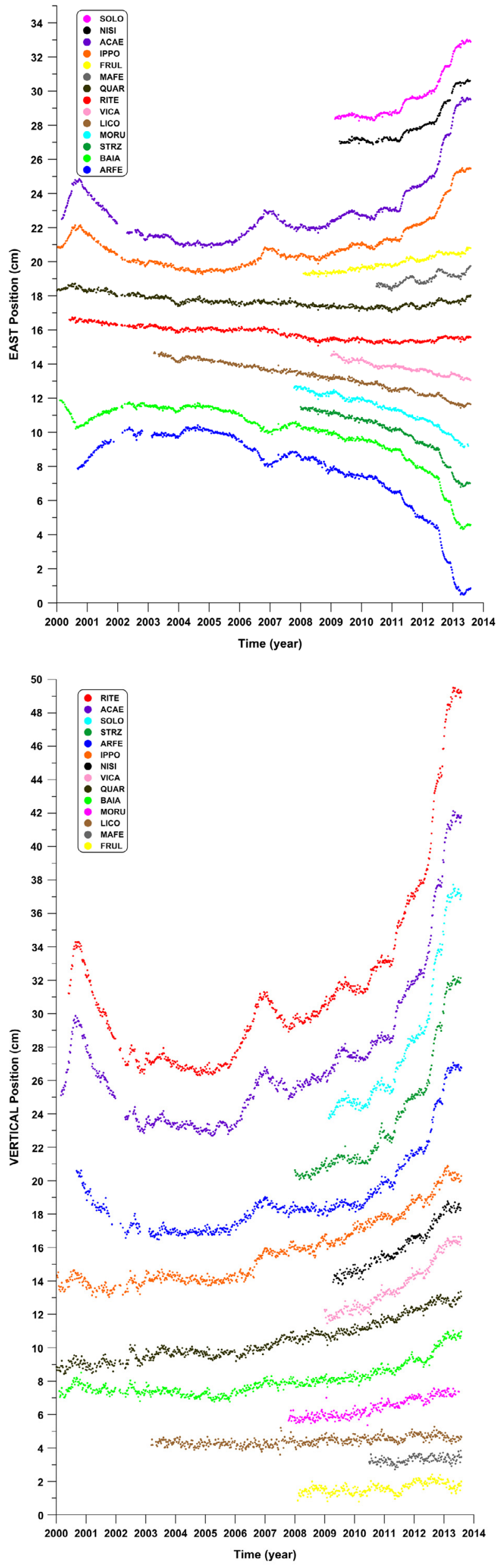
et al. 2011, Tammaro et al. 2013]. We simply remove the ENAV horizontal GPS velocities $(16.5 \mathrm{~mm} / \mathrm{yr}$ and $21.3 \mathrm{~mm} / \mathrm{yr}$, in the North and East component respectively) from all GPS time series of the CF area, while the vertical (Up) components were untouched.

The deformation signal does not have significant changes on timescales shorter than a week, so we use weekly combined solutions. As an indicator of realistic uncertainties of the weekly positions, we use the RMS of daily solutions with respect to the weekly solution, the so-called repeatabilities [Steigenberger et al. 2012]. The mean RMS values are less than $1 \mathrm{~mm}$ and $3 \mathrm{~mm}$ in the horizontal and vertical components, respectively.

Figures 2, 3 and 4 show the final GPS weekly position time series for the stations at CF from 2000 to July 2013. In the Supplementary material, we report the complete archive in ASCII format of all the GPS time series used in this paper.

\section{Discussion}

GPS data at all the continuous recording stations from 2000 to 2013 are shown in Figures 2, 3 and 4 displaying the whole evolution of the subsidence and uplift.

During this period, the RITE station, located at the center of Pozzuoli, has the largest associated uplift, of about $18.5 \mathrm{~cm}$ (Figure 5). The ACAE, ARFE, SOLO, STRZ stations (Figure 4), located within about $3 \mathrm{~km}$ from RITE, have smaller vertical displacements from 6 $\mathrm{cm}$ (ARFE) up to $17 \mathrm{~cm}$ (ACAE). The other stations, located over $3 \mathrm{~km}$ from RITE, have vertical displacements from less than $1 \mathrm{~cm}$ (MAFE, FRUL) up to $6 \mathrm{~cm}$ (IPPO). Figures 2 and 3 show that the SOLO, ACAE, IPPO, FRUL and MAFE stations have horizontal displacements in NE direction. The RITE, VICA, LICO, MORU, STRZ and RITE sites have horizontal displacements in NW direction. NISI has a displacement towards SE and BAIA in SW direction. Only QUAR has a horizontal displacement mainly to North.

As mentioned in the introduction, $\mathrm{CF}$ are known worldwide to be a site of notable slow vertical ground movements (uplift and subsidence) and, as noted in several papers [e.g. De Natale and Pingue 1993, De Natale et al. 1997], the shape of vertical ground deformation pattern is remarkably constant, independent from the total amount of displacement. This characteristic behavior suggests that the position of the source is always the same. The precise modeling of displacement sources generally requires a dense geodetic data sampling, therefore it is possible to use continuous GPS measurements to extract basic information about source geometry and depth.
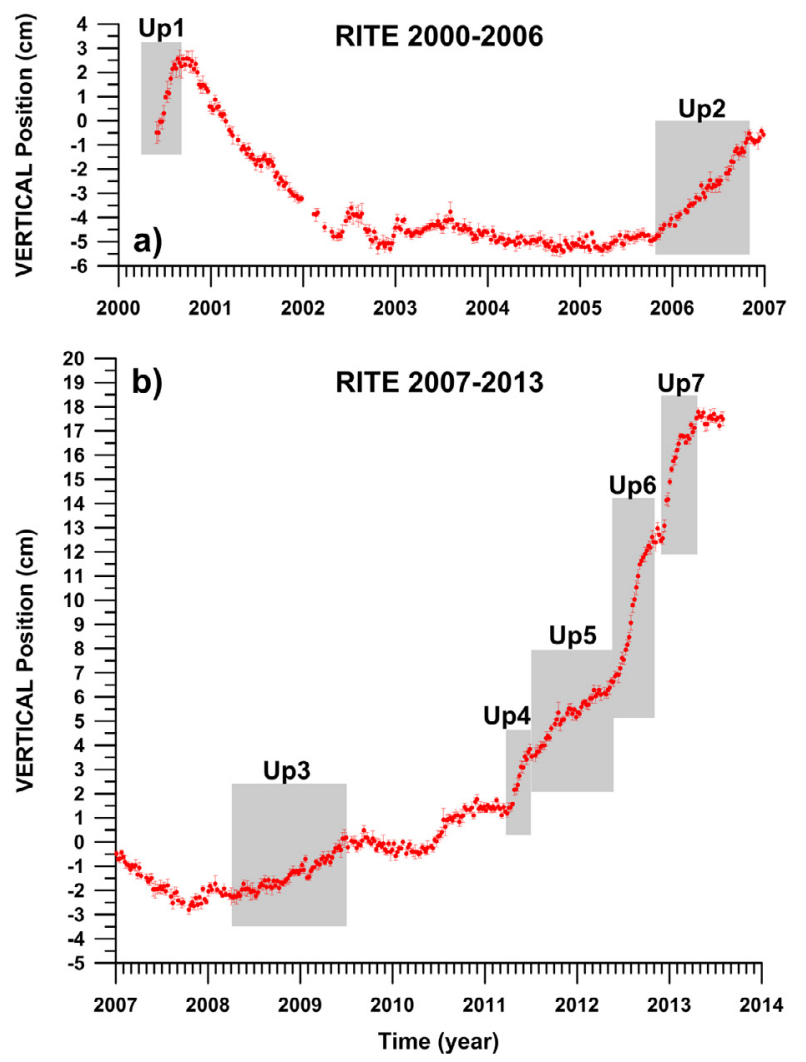

Figure 5. GPS weekly time series of Vertical component for station RITE: (a) 2000-2006 time span; (b) 2007-2013 time span. The gray box indicate the selected seven uplift periods (Up1, Up2...,Up7).

During period 2000-2013, we have identified, in the RITE time series, 7 episodes of uplift with time span greater than 0.23 years and/or a speed greater than $18 \mathrm{~mm} / \mathrm{yr}$. Figure 5 shows the horizontal displacements observed during the selected 7 uplift period. Simple geometrical considerations (crossing point of the displacement vectors for each uplift) suggest a stable source location. Therefore, for each uplift episode, we jointly invert the horizontal and vertical displacements measured at GPS stations. We have used dMODELS software package [Battaglia et al. 2013a,b], which provides MATLAB functions and scripts to invert GPS data for spherical pressure source in a homogenous, isotropic, elastic, flat half-space. The seven sources obtained by the inversion results $\left(0.4<\chi^{2}<1.1\right)$ are concentrated in an area (South of RITE station, Figure 6) of $130 \times 260 \mathrm{~m}$ at depth ranging between 2400 and $3000 \mathrm{~m}$.

Although the real conditions might be much more complex, it seems plausible to assume a constant position of the source of ground deformation. Nevertheless, it is unequivocal that the location of the axis of the pressure source is remarkably constantly, although the source depth and shape can change [De Natale and Pingue 1993, De Natale et al. 1997]. Therefore, simulations with more complex sources in heterogeneous structures are needed. 

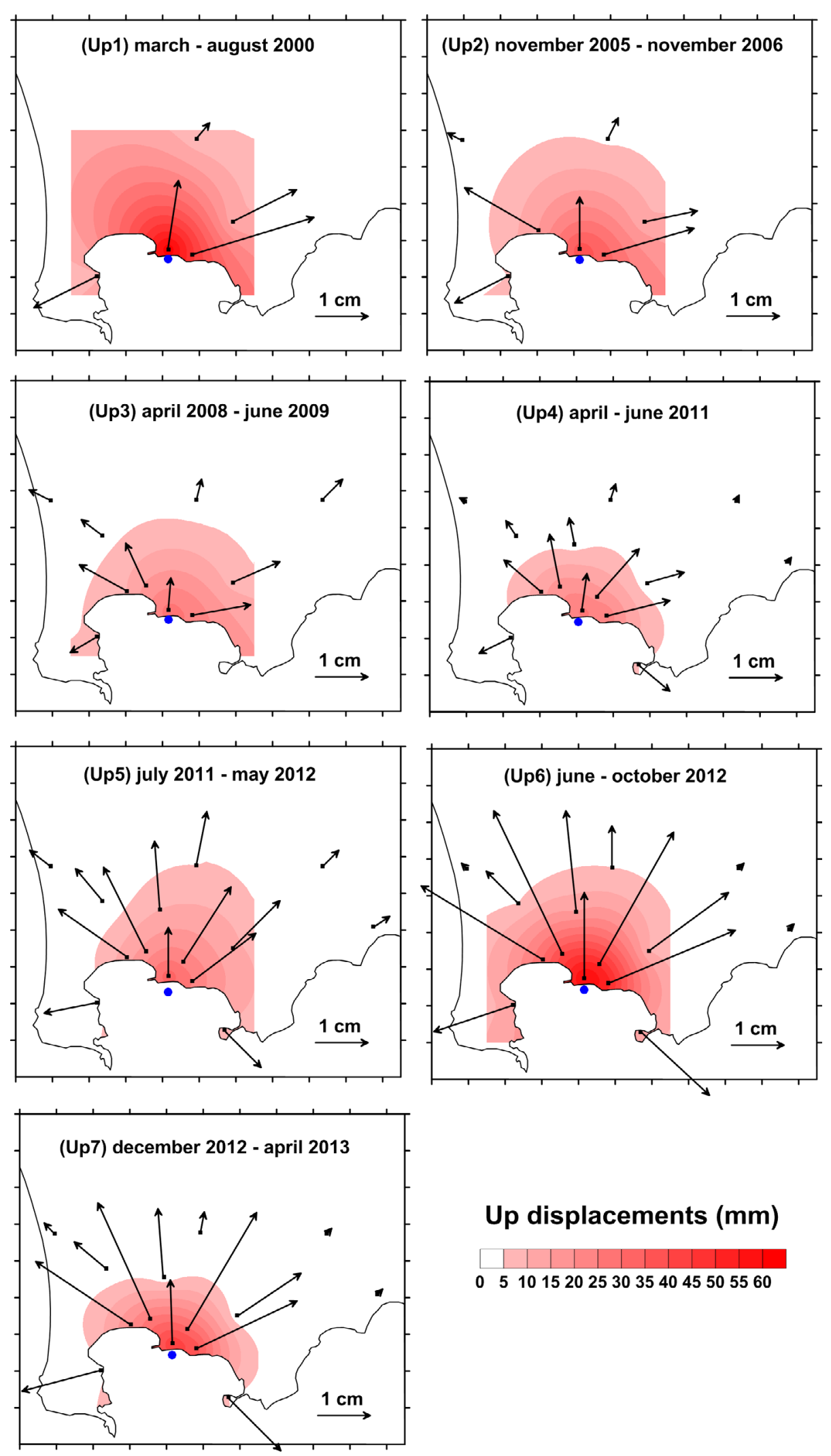

\section{Up displacements $(\mathrm{mm})$}

051015202530354045505560

Figure 6. The vectors show the magnitude and direction of displacement of each continuous GPS station during the selected 7 uplift periods in Figure 5. For each period have shown the position of the source obtained by means joint inversion of horizontal and vertical displacements, and uplift map.

\section{Conclusion}

In this paper we have presented the part of the NeVoCGPS network that includes CF caldera. We have described data recording and data processing of the complete dataset of GPS time series at CF caldera from 2000 to July 2013. The CF caldera appears to be in a constant motion both in uplifting and in dowlifting, and NeVoCGPS network has been able to meas- 
ure uplift and subsidence during period 2000-2013.

Simple geometrical considerations, and jointly inversion of the horizontal and vertical displacements measured at GPS stations seem to suggest a stable source location during the time interval from 2000 to 2013. Nevertheless, complex models with one or more sources and heterogeneous half-space are needed.

The complete dataset of GPS time series at CF area from 2000 to July 2013 is reported in the Supplementary materials. These data can be useful for the scientific community in improving the research on $\mathrm{CF}$ caldera dynamic and hazard assessment.

Acknowledgements. The authors thank Giuseppe Brandi, Andrea D'Alessandro, Mario Dolce, Santa Malaspina and Claudio Serio, who have taken care of the maintenance of NeVoCGPS network. We are grateful to the Laboratorio di Geomatica e Cartografia (INGV-OV) for providing the DTM (Digital Terrain Model) of the area. This research benefited from funding provided by the Italian Presidenza del Consiglio dei Ministri - Dipartimento della Protezione Civile (DPC). Scientific papers funded by the DPC do not represent its official opinions and policies.

\section{References}

Altamimi, Z., X. Collilieux, J. Legrand, B. Garayt and C. Boucher (2007). ITRF2005: A new release of the International Terrestrial Reference Frame based on time series of station positions and Earth Orientation Parameters, J. Geophys. Res., 112, B09401; doi:10.1029/2007JB004949.

Arienzo, I., A. Heumann, G. Wörner, L. Civetta and G. Orsi (2011). Processes and timescales of magma evolution prior to the Campanian Ignimbrite eruption (Campi Flegrei, Italy), Earth and Planet. Sc. Lett., 306, 217-228; doi:10.1016/j.epsl.2011.04.002.

Barberi, F., G. Corrado, F. Innocenti and G. Luongo (1984). Phlegraean Fields 1982-1984: brief chronicle of a volcano emergency in a densely populated area, B. Volcanol., 47 (2), 175-185.

Battaglia, M., P.F. Cervelli and J.R. Murray (2013a). Modeling crustal deformation near active faults and volcanic centers - A catalog of deformation models: U.S. Geological Survey Techniques and Methods, book 13, chap. B1, 96 pp.; http:/ / pubs.usgs.gov/tm/ $13 / \mathrm{b} 1$.

Battaglia, M., P.F. Cervelli and J.R. Murray (2013b). dMODELS: A MATLAB software package for modeling crustal deformation near active faults and volcanic centers, J. Volcanol. Geoth. Res., 254, 1-4, ISSN 0377-0273; http:/ / dx.doi.org/10.1016/j.jvolgeores. 2012.12.018.

Berrino, G., G. Corrado, G. Luongo and B. Toro (1984). Ground deformation and gravity change accompanying the 1982 Pozzuoli uplift, B. Volcanol., 47 (2), 187-200.
Bottiglieri, M., M. Falanga, U. Tammaro, P. De Martino, F. Obrizzo, C. Godano and F. Pingue (2010). Characterization of GPS time series at Neapolitan volcanic area by statistical analysis, J. Geophys. Res., 115, B10416; doi:10.1029/2009JB006594.

Corrado, G., I. Guerra, A. Lo Bascio, G. Luongo and F. Rampoldi (1977). Inflation and microearthquake activity of Phegraean Fields, Italy, B. Volcanol., 40 (3), 169-188.

Dach, R., U. Hugentobler, P. Fridez and M. Meindl (2007). Bernese GPS Software version 5.0, Astronomical Institute, University of Bern, Switzerland.

Deino, A.L., G. Orsi, S. de Vita and M. Piochi (2004). The age of the Neapolitan Yellow Tuff calderaforming eruption (Campi Flegrei caldera - Italy) assessed by $40 \mathrm{Ar} / 39 \mathrm{Ar}$ dating method, J. Volcanol. Geoth. Res., 133, 157-170; doi:10.1016/S0377-0273 (03)00396-2.

Del Gaudio, C., I. Aquino, G.P. Ricciardi, C. Ricco and R. Scandone (2010). Unrest episodes at Campi Flegrei: a reconstruction of vertical ground movements during 1905-2009, J. Volcanol. Geoth. Res., 185, 48-56.

De Martino, P., U. Tammaro, F. Obrizzo, V. Sepe, G. Brandi, A. D'Alessandro, M. Dolce and F. Pingue (2011). La rete GPS dell'isola d'Ischia: deformazioni del suolo in un'area vulcanica attiva (1998-2010), Quaderni di Geofisica, 95, 59 pp., ISSN 1590-2595.

De Natale, G., F. Pingue, P. Allard and A. Zollo (1991). Geophysical and geochemical modelling of the 19821984 unrest phenomena at Campi Flegrei caldera, southern Italy, J. Volcanol. Geoth. Res., 48, 199-222.

De Natale, G., and F. Pingue (1993). Ground deformations in collapsed caldera structures, J. Volcanol. Geoth. Res., 57, 19-38.

De Natale, G., S.M. Petrazzuoli and F. Pingue (1997). The effect of collapse structures on ground deformations in calderas, Geophys. Res. Lett., 24, 15551558.

Di Vito, M.A., L. Lirer, G. Mastrolorenzo and G. Rolandi (1987). The Monte Nuovo eruption Campi Flegrei, Italy, B. Volcanol., 49, 608-615.

Dow, J.M., R.E. Neilan and C. Rizos (2009). The International GNSS Service in a changing landscape of Global Navigation Satellite Systems, J. Geodesy, 83, 191-198; doi:10.1007/s00190-008-0300-3.

Estey, L., and C. Meertens (1999). TEQC: The MultiPurpose Toolkit for GPS / GLONASS Data, GPS Solutions, 3 (1), 42-49.

Fedele, L., L. Scarpati, M. Lanphere, L. Melluso, V. Morra, A. Perrotta and G. Ricci (2008). The Breccia Museo formation, Campi Flegrei, southern Italy: geochronology, chemostratigraphy and relationship with the Campanian Ignimbrite eruption, B. Volcanol., 
70, 1189-1219.

Finetti, I., and A. Del Ben (1986). Geophysical study of the Tyrrhenian opening, B. Geofis. Teor. Appl., 27, 74-115.

Günther, R.T. (1903). Contribution to the study of earth movements in the Bay of Naples, Oxford.

Isaia, R., P. Marianelli and A. Sbrana (2009). Caldera unrest prior to intense volcanism in Campi Flegrei (Italy) at 4.0 ka B.P.: implications for caldera dynamics and future eruptive scenarios, Geophys. Res. Lett., 36, L21303; doi:10.1029/2009GL040513.

Luongo, G., E. Cubellis, F. Obrizzo and S.M. Petrazzuoli (1991a). A physical model for the origin of volcanism of the Tyrrhenian margin: the case of the neapolitan area, J. Volcanol. Geoth. Res., 48, 173-185.

Luongo, G., E. Cubellis, F. Obrizzo and S.M. Petrazzuoli (1991b). The mechanics of the Campi Flegrei resurgent caldera - a model, J. Volcanol. Geoth. Res., 45, 161-172.

Mervart, L., G. Beutler, M. Rothacher and U. Wild (1994). Ambiguity resolution strategies using the results of the International GPS Geodynamics Service (IGS), B. Geod., 68, 29-38.

Morhange, C., M. Bourcier, J. Laborel, C. Giallanella, J.P. Goiran, L. Crimaco and L. Vecchi (1999). New data on historical relative sealevel movements in Pozzuoli, Phlaegrean Fields, Southern Italy, Phys. Chem. Earth (part A), 24, 349-354.

Morhange, C., N. Marriner, J. Laborel, M. Todesco and C. Oberlin (2006). Rapid sea-level movements and non eruptive crustal deformations in the Phlegrean Fields caldera, Italy, Geology, 34, 93-96; doi:10.1130/ G21894.1.

Niell, A.E. (1996). Global mapping functions for the atmosphere delay at radio wavelength, J. Geophys. Res. Solid Earth, 101 (B2), 3227-3246.

Parascandola, A. (1947). I Fenomeni Bradisismici del Serapeo di Pozzuoli, Stabilimento Tipografico G. Genovese, Naples.

Patacca, E., and P. Scandone (2007). Geology of the Southern Apennines, B. Soc. Geol. Ital., 7, 75-119.

Rebischung, P., J. Griffiths, J. Ray, R. Schmid, X. Collilieux and B. Garayt (2012). IGS08: the IGS realization of ITRF2008, GPS Solutions, 1-12; doi:10.1007/s10291011-0248-2.

Ricci, T., F. Barberi, M.S. Davis, R. Isaia and R. Nave (2013). Volcanic risk perception in the Campi Flegrei area, J. Volcanol. Geoth. Res., 254, 118-130; doi:10.1016/j.jvolgeores.2013.01.002.

Rosi, M., and A. Sbrana (1987). Phlegraean Fields, Quaderni de "La Ricerca Scientifica”, CNR, Roma, 114, 114-175.

Schmid, R., P. Steigenberger, G. Gendt, M. Ge and M.
Rothacher (2007). Generation of a consistent absolute phase center correction model for GPS receiver and satellite antennas, J. Geodesy, 81 (12), 781-798; doi:10.1007/ s00190-007-0148-y.

Steigenberger, P., M. Rothacher, R. Dietrich, M. Fritsche, A. Rulke and S. Vey (2006). Reprocessing of a global GPS network, J. Geophys. Res., 111, B050402; doi:10. $1029 / 2005 J B 003747$.

Steigenberger, P., M. Seitz, S. Bockmann, V. Tesmer and U. Hugentobler (2012). Precision and Accuracy of GPS-derived Station Displacements, Phys. Chem. Earth, 53/54, 72-79; doi:10.1016/j.pce.2010.07.035

Tammaro, U., P. De Martino, F. Obrizzo, G. Brandi, A. D’Alessandro, M. Dolce, S. Malaspina, C. Serio and F. Pingue (2013). Somma Vesuvius volcano: ground deformations from CGPS observations (2001-2012), Annals of Geophysics, 56 (4), S0456; doi:10.4401/ag6462.

Troise, C., G. De Natale, F. Pingue, F. Obrizzo, P. De Martino, U. Tammaro and E. Boschi (2007). Renewed ground uplift at Campi Flegrei caldera (Italy): New insight on magmatic processes and forecast, Geophys. Res. Lett., 34, L03301; doi:10.1029/2006GL028 545, ISSN 0094-8276.

Vezzani, L., A. Festa and F. Ghisetti (2010). Geology and Tectonic Evolution of the Central-Southern Apennines, Italy, Geological Society of America, Special Paper 469, 1-58.

Vilardo, G., R. Isaia, G. Ventura, P. De Martino and C. Terranova (2010). InSAR Permanent Scatterer analysis reveals fault re-activation during inflation and deflation episodes at Campi Flegrei caldera, Remote Sens. Environ., 114, 2373-2383; doi:10.1016/j.rse.2010. 05.014 .

\footnotetext{
${ }^{\star}$ Corresponding author: Prospero De Martino, Istituto Nazionale di Geofisica e Vulcanologia, Sezione di Napoli, Osservatorio Vesuviano, Naples, Italy; email: prospero.demartino@ov.ingv.it.

(C) 2014 by the Istituto Nazionale di Geofisica e Vulcanologia. All rights reserved.
} 